Article

\title{
Potential Role for Consumers to Reduce Canadian Agricultural GHG Emissions by Diversifying Animal Protein Sources
}

\author{
James A. Dyer ${ }^{1, *}$, Raymond L. Desjardins ${ }^{2}$, Devon E. Worth ${ }^{2}$ and Xavier P.C. Vergé ${ }^{2}$ \\ 1 Agriculture and Agri-Food Canada, 122 Hexam Street, Cambridge, ON N3H 3Z9, Canada \\ 2 Science and Technology Branch, Agriculture and Agri-Food Canada, Government of Canada, 960 Carling \\ Avenue, Ottawa, ON K1A 0C6, Canada; ray.desjardins@canada.ca (R.L.D.); \\ devon.worth@canada.ca (D.E.W.); xavier.vrg@gmail.com (X.P.V.) \\ * Correspondence: jamesdyer@sympatico.ca; Tel.: +1-519-653-2995
}

Received: 9 June 2020; Accepted: 3 July 2020; Published: 7 July 2020

check for updates

\begin{abstract}
The discussion of diversified protein sources triggered by the 2019 Canadian Food Guide has implications for Canada's livestock industry. In response to this discussion, a scenario analysis is conducted on the potential impact of reducing red meat consumption on the greenhouse gas (GHG) emissions from Canadian livestock production. This analysis uses medical recommendations as a proxy for healthy servings of red meat. For simplicity, it was assumed that red meat is either beef or pork and that broilers are the only nonred meat choice. The medical scenario is combined with four livestock production scenarios for these three livestock types. Broiler consumption is allowed to expand to maintain national protein intake in all four scenarios. Under the medical scenario, red meat consumption in Canada would decrease from $2.5 \mathrm{Mt}$ to $1.9 \mathrm{Mt}$ of live weight. A feedlot diet for slaughter cattle, and a 50:50 split of the medically recommended red meat intake of beef and pork (Scenario 1), reduced GHG emissions by $3.9 \mathrm{MtCO}_{2} \mathrm{e}$ from the $20.6 \mathrm{Mt} \mathrm{CO}_{2} \mathrm{e}$ (carbon dioxide equivalent) for current consumption. Replacing the feedlot beef diet by grass fed beef (Scenario 2) increased GHG emissions by $1.5 \mathrm{MtCO}_{2} \mathrm{e}$ over Scenario 1. Halving the consumption of grass fed beef and increasing pork by $50 \%$ (Scenario 3) reduced GHG by $7.7 \mathrm{Mt} \mathrm{CO}_{2} \mathrm{e}$. Reverting back to the feedlot diet, and the same 25:75 beef-pork ratio (Scenario 4), increased the GHG emissions reduction to $8.9 \mathrm{Mt}$ $\mathrm{CO}_{2} \mathrm{e}$. Without including the emission savings from the medical scenario, GHG reductions from Scenarios 3 and 4 dropped to $3.8 \mathrm{Mt}$ and $5.0 \mathrm{Mt} \mathrm{CO}_{2} \mathrm{e}$, respectively. No scenario exceeded the feed grain area required to meet the 2017 consumption of these commodities, but Scenario 2 required more forage area compared to consumption in 2017.
\end{abstract}

Keywords: national protein intake; scenario analysis; red meat; greenhouse gases; livestock carcass commodities; live weights; beef diet; livestock crop complex; cropland

\section{Introduction}

Hedenus et al. [1] concluded that reduced meat consumption will be indispensable in mitigating agricultural greenhouse gas (GHG) emissions and that human dietary choice is an important parameter in implementing this reduction. This conclusion was supported by the Food and Agriculture Organization of the United Nations (FAO) [2]. The 2019 Canada Food Guide, recently published by the Government of Canada [3], recommended diversifying protein sources towards nuts, beans, legumes, pulses and tofu, along with eggs and dairy products [4]. This diversification could cause a much larger share of Canada's protein intake to come from nonmammal sources [5], which could enhance the sustainability of Canadian agriculture. Dyer et al. [6] undertook an analysis to determine 
the potential impact that this change in the human diet would have on GHG emissions from the Canadian livestock industry.

The 2019 Canada Food Guide avoided offering quantitatively measured serving portions [3,7]. Because of this qualitative limitation, Dyer et al. [6] used six published medical recommendations for lowering red meat (RM) consumption as a proxy for the serving portions implied in the 2019 Canada Food Guide. It should be cautioned that, even though most medical sources [6] and the Canada Food Guide [3] define RM as including all mammalian muscle tissue, not all countries would necessarily consider pork to be RM. A review of dietary patterns in Ontario, Canada [8] highlighted the positive impacts that substantially reducing animal protein consumption would have on public health in that province. Heller and Keoleian [9] identified overconsumption of meats as a health risk in the USA. However, Dyer et al. [6] only assessed the impact of reducing RM consumption on the GHG emissions budget of Canadian livestock production, without assessing the efficacy of the medical argument for reducing $\mathrm{RM}$.

Dyer et al. [6] formulated a series of scenarios that integrated the medical recommendations with several possible responses by livestock producers. This scenario analysis used beef and pork to represent Canadian RM consumption, while allowing broiler consumption to expand in order to maintain the national protein intake (NPI) in Canada. Hence, the GHG emission calculations had an upper boundary condition of recommended RM consumption and a lower boundary condition defined by maintaining NPI, where NPI was defined by the total protein contents of the beef, pork and broilers consumed in Canada in 2017 [10]. In general, Dyer et al. [6] did not disaggregate these scenarios into the medical and production components, and the findings were not related to the GHG emissions budget of the whole Canadian agriculture sector. More importantly, it did not assess how much land would be required to either achieve the scenarios or whether any of the scenarios would require more cropland than would be available in Canada.

The first goal of this analysis is to separate the Canadian consumer response options related to meat consumption from the livestock management options in order to engage Canadian consumers in reducing the carbon footprint of the agriculture sector. This goal requires the disaggregation of the set of scenarios presented by Dyer et al. [6] to quantify the GHG emissions of these disaggregated components. The second goal of this analysis is to assess the implications of the findings for sustainable agricultural land use in Canada. The third goal is to determine the potential contribution of the components of the scenarios to the $72 \mathrm{MtCO}_{2} \mathrm{e}$ (carbon dioxide equivalent) emitted by all components of the Canadian agriculture sector in 2017 [11]. In keeping with the original assessment [6], the spatial scale of this analysis is Canada-wide and the year of interest is 2017.

\section{Methodology}

The starting point of this analysis was provided by Dyer et al. [6]. The contributions from that paper to this analysis were: (1) GHG emission intensity coefficients for beef, pork and broilers; (2) an unpublished estimate of the GHG emission intensity for grass fed beef; (3) medically based scenarios for red meat consumption; (4) broilers as the representative nonred meat protein source; (5) 2017 consumption of animal protein in Canada; and (6) three of the four production scenarios used in this analysis. The new components of this analysis are: (1) the fourth production scenario; (2) the first and second order differences among the four scenarios; (3) the projection of cropland areas needed to satisfy the 2017 Canadian consumption and the four scenarios; (4) the role of those areas in the sustainability of livestock production; (5) the impacts of the four scenarios on the GHG emissions and cropland areas of Canadian agriculture; (6) and an in-depth analysis of the implications of the findings for Canadian consumers.

\subsection{GHG Emission Estimates}

In order to quantify the GHG emissions from beef, pork and broilers, Dyer et al. [6] adapted the estimates published by Vergé et al. [12-14] for these commodities for the census years from 1981 to 
2006. Although the methods used by Vergé et al. [12-14] were later unified under one spreadsheet model [15], the unified model relied on inputs that were only available from detailed census records. All of these calculations took account of $\mathrm{CH}_{4}, \mathrm{~N}_{2} \mathrm{O}$ and fossil $\mathrm{CO}_{2}$ emissions directly from the livestock, their manure and the crop complexes that support these livestock.

Dyer et al. [6] developed a simple metamodel for estimating the national GHG emissions from these three commodities driven by their market live weights $(\mathrm{LW})$. The metamodel consisted of the $\mathrm{tCO}_{2} \mathrm{e} / \mathrm{tLW}$ emission intensity coefficients for each of the three commodities that were fitted to the respective commodities over the six census years, 1981 to 2006. These coefficients were 10.5, 2.2 and $1.4 \mathrm{tCO}_{2} \mathrm{e} / \mathrm{tLW}$ for beef, pork and broilers, respectively. The emission intensity coefficients from the metamodel were within $5 \%$ of the original national $\mathrm{TgCO}_{2}$ e estimates for all three commodities [12-14]. Poore and Nemecek [16] have shown a similar hierarchy in the relationships among the GHG emission rates of these three livestock types.

Broilers, a non-RM carcass commodity, were included with the two RM commodities, beef and pork, because an increase in non-RM protein sources would be needed to maintain the NPI as the projected RM consumption is reduced [6]. Protein is an ideal common denominator for comparing livestock GHG emissions [10,17]. However, this indicator does not account for livestock by products, which, at least for beef, can have appreciable market value [18]. A variation of the GHG-protein indicator applied to the Swiss dairy industry used weight of milk corrected for protein content to assess the sustainability of that industry [19].

The protein-based GHG emission intensity indicator $[17,20]$ defined the minimum boundary condition for the recommended livestock consumption calculations. The latest of the six census years common to the three source papers and with both GHG and land use estimates [12-14] was 2001. GHG emissions from producing beef, pork and broilers in 2001, were projected to 2017 based on 2017 livestock population survey records from the same data source [21] used in the metamodel [6] for 2001. The production-related GHG emission estimates and the LW of the market animals from these livestock types used to make these projections are shown in Table 1 for 2001 and 2017. The production related data shown in Table 1 for the three livestock types were the main inputs to this analysis. The GHG emissions and the LW values were generated by Dyer et al. [6] from the three livestock assessments [12-14]. Crop areas for 2017, the only inputs from Table 1 generated in this analysis (Section 3.2), were projected forward from the 2001 crop areas [12-14].

Table 1. Greenhouse gas (GHG) emissions from the Production (P) of beef, pork and broilers in Canada, the Live weights (LW) of the market animals, and the crop areas required to produce those three commodities for 2001 and 2017.

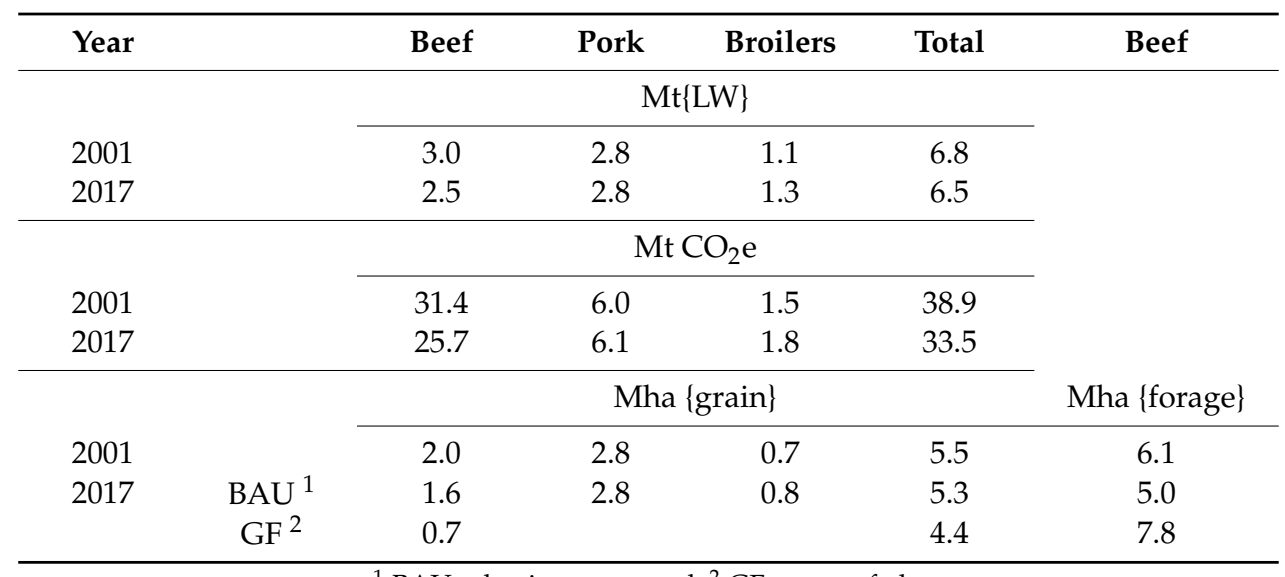

${ }^{1} \mathrm{BAU}=$ business as usual $^{2} \mathrm{GF}=$ grass fed.

Figure 1 shows the GHG emissions based on the metamodel described by Dyer et al. [6] for the 2001 production $(\mathrm{P})$ of the three livestock commodities (white bars) in comparison to the 2001 
production-related GHG emission estimates [12-14] (grey bars). Figure 1 also shows the 2001 GHG emissions projected to 2017 (black bars) based on the GHG metamodel [6]. As expected, the differences between the two sets of estimates for 2001 were very small relative to the differences among the three carcass types. For pork and broilers, there was almost no change from 2001 to 2017, based on the metamodel [6]. For beef, the metamodel [6] projected about a 20\% decrease from 2001 to 2017, based on a decline in the Canadian beef cattle population over that period [21].

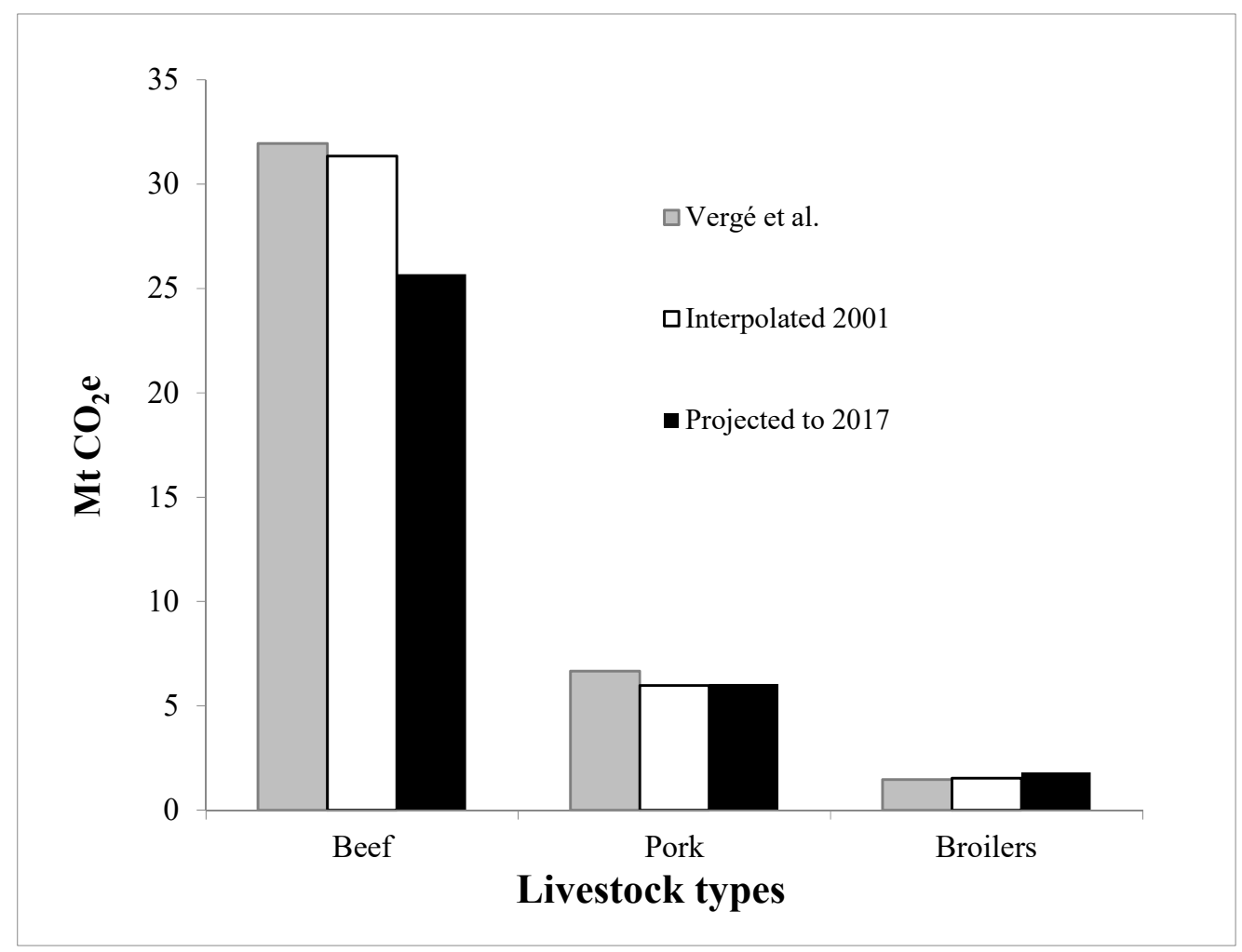

Figure 1. Greenhouse gas (GHG) emissions from the production (P) of beef, pork and broilers in Canada, calculated by Vergé et al. [12-14] for 2001 and estimated by Dyer et al. [6] for 2001 and 2017.

While $\mathrm{CH}_{4}, \mathrm{~N}_{2} \mathrm{O}$ and $\mathrm{CO}_{2}$ (both fossil and soil) all define the carbon footprint of livestock production, beef-pork carbon footprint differences were most sensitive to $\mathrm{CH}_{4}$. The ruminant digestion associated with beef creates several gases. However, methane is the only significant GHG generated from this process. On a unit of protein basis, the Canadian beef industry generates six times as much methane as the Canadian pork industry [10]. For beef cattle, $98 \%$ of the methane emitted was enteric methane, with manure storage accounting for the remaining 2\% [22]. For pork, $87 \%$ of the emitted methane was from manure storage while only $13 \%$ was enteric [22].

\subsection{Production Scenarios}

Dyer et al. [6] assumed three medical scenarios based on three levels of reduced RM consumption. In order to put more focus on farm level production decisions, this analysis only used one medical scenario based on the average of the six medical recommendations for reduced RM cited in the previous scenario analysis [6]. This average recommended per person RM consumption of $21.3 \mathrm{~kg} / \mathrm{year}$ of cooked RM would reduce national RM consumption to $1.9 \mathrm{Mt}$ of LW, instead of the 2.5 Mt of LW consumed in 2017 [23]. Since this medical recommendation was applied to all of the production scenarios (PS) in this analysis, none of the PS needed to be replicated.

PS-1, the first of the four PS, entailed a 50:50 split of the RM allowed by the medical recommendation between beef and pork, and a business as usual (BAU) approach to the diet for the beef cattle destined for slaughter [6]. The BAU beef diet was based on feedlot finishing steers and slaughter heifers with 
increased rations of feed grain [12,24]. The second production scenario (PS-2) kept the same 50:50 split of the allowed RM between beef and pork, but assumed that the cattle destined for slaughter would be grass fed (GF) [6]. Although the difference between PS-1 and PS-2 reflects the impact that these two beef diets have on enteric $\mathrm{CH}_{4}$ emissions [25], it does not include the avoided soil carbon losses associated with GF beef [26]. The third production scenario (PS-3) kept the same GF beef diet as assumed in PS-2, but the beef consumption allowed in PS-1 and PS-2 was cut in half to permit $50 \%$ more pork, resulting in a 25:75 beef-pork split in RM consumption [6]. The fourth production scenario (PS-4) added to this analysis assumed the same 25:75 beef-pork split as assumed in PS-3, but the diet for slaughter cattle in PS-4 reverted back to the same BAU beef diet that was assumed for PS-1, rather than the GF beef diet assumed for PS-2 and PS-3 [6].

PS-2 is essential in evaluating GF beef as a carbon sequestration strategy $[25,26]$. The GHG emission estimates from GF beef [6] relied on unpublished output from the unified version of the model for livestock [15] that gave GHG emission rates for all of the age-gender categories of beef cattle. Dyer et al. [27] showed that slaughter cattle could be treated like replacement heifers with respect to diet and lifespan to differentiate them from feedlot steers and slaughter heifers. The effect of the GF diet for slaughter cattle was more forage and less feed grain intake by the beef population compared to the BAU diet [6]. Treated as replacement heifers, feed grain intake per head for these steers and slaughter heifers was only $6 \%$ of the feed grain intake that they would have had as feedlot slaughter animals. The age-gender diet differences were those reported by Elward et al. [28]. The GHG emissions coefficient for GF beef was $12.7 \mathrm{tCO}_{2} \mathrm{e} / \mathrm{tLW}$, which was $21 \%$ higher than the $10.5 \mathrm{tCO}_{2} \mathrm{e} / \mathrm{tLW}$ coefficient for BAU beef [6]. This difference between GHG emission rates for beef is consistent with the diet-related differences in GHG emission rates reported by Desjardins et al. [18] for a range of other beef producing countries.

With the focus on consumer options, the reference quantity for this analysis was animal protein consumption (C), rather than P. The GHG emissions for the 2017 C and for each PS are shown in Table 2. For each PS, the GHG emission total includes all three livestock types. Agriculture and Agri-food Canada [23] provided carcass weights (CW) for Canadian consumption of all three carcass commodities for 2017. These CW data were converted to LW using coefficients from Dyer et al. [10]. The CW data for beef and pork consumption [18] were within 5\% of the estimates of the Canadian consumption of these two commodities from the Organization for Economic Co-operation and Development (OECD) [29]. Dyer et al. [6] used the LW ratios of $C$ to $P$ for each commodity to interpolate the GHG emissions associated with C from the GHG emissions for P for each livestock type [12-14].

Table 2. Total GHG emissions from the three livestock commodities from the 2017 Canadian consumption (C) and the four production scenarios (PS-1 to PS-4), and the first and second order differences in GHG emissions described in this paper.

\begin{tabular}{cccccc}
\hline & C & PS-1 & PS-2 & PS-3 & PS-4 \\
\hline \multicolumn{5}{c}{ Mt CO $_{2} \mathrm{e}$} \\
\hline Total GHG & 20.6 & 16.7 & 19.1 & 12.9 & 11.7 \\
$\Delta$ PS- $n^{1}$ & & 3.9 & 1.5 & 7.7 & 8.9 \\
$\Delta^{2}$ PS- $n^{2}$ & & -2.5 & 3.8 & 5.0 \\
$\Delta^{2}$ PS-4 ${ }^{3}$ & & 1 & 2 & 3 & 4
\end{tabular}

${ }^{1}$ first order differences ( $\Delta$ PS- $n=$ C - PS- $\left.n\right),{ }^{2}$ second order differences $\left(\Delta^{2}\right.$ PS $-n=\Delta$ PS- $n-\Delta$ PS- 1$),{ }^{3}$ second order difference for PS4 ( $\Delta^{2}$ PS- $4=\Delta^{2}$ PS-3 $-0.5 \Delta^{2}$ PS-2).

Table 2 also presents the estimated GHG emission differences $\left(\mathrm{Mt} \mathrm{CO}_{2} \mathrm{e}\right)$ between the four PS and C. For the purpose of this paper, these quantities are considered to be first order differences ( $\triangle \mathrm{PS}-n$, where $n=1$ to 4 ). Each first order difference is the residual GHG emissions after subtracting the GHG emissions from each respective PS from the GHG emissions from C. Additionally of interest in this 
analysis was to separate the effect of the medical RM recommendation from the production related decisions in each PS, particularly PS-3 and PS-4. Because of the BAU beef diet in PS-1, $\triangle$ PS-1 represents the medical RM recommendation. Cancelling out the medical RM recommendation was achieved by defining the second order differences. Each second order difference ( $\Delta^{2} P S-n$, where $n=2$ to 4 ) was the GHG emissions difference between $\Delta$ PS- $n$ and $\Delta$ PS-1. For $\Delta^{2}$ PS-2 and $\Delta^{2}$ PS-3, the differences from $\triangle \mathrm{PS}-1$, instead of $\mathrm{C}$, was all that was required to nullify the medical recommendation.

PS-4 was calculated from the second order difference for PS-4 ( $\Delta^{2}$ PS-4). Calculating this second order difference required the second order differences for PS-3 ( $\Delta^{2}$ PS-3) and for PS-2 ( $\Delta^{2}$ PS-2). With its negative sign, $\Delta^{2}$ PS-2 reflected the increase (rather than reduction) in GHG emissions from BAU back to GF for slaughter cattle. Because beef consumption in PS-4 was half of the beef consumption in PS-2, only half of the second order difference of PS-2 was required for PS-4. This correction for $\Delta^{2}$ PS-2 was required because part of $\Delta^{2}$ PS- 2 was already embedded in PS-3. $\Delta^{2}$ PS- 4 isolated the impact of changing the beef-pork split (from 50:50 to 25:75) from both the beef diet and the medical RM recommendation. $\Delta^{2} \mathrm{PS}-4$ was calculated as follows:

$$
\Delta^{2} \mathrm{PS}-4=\Delta^{2} \mathrm{PS}-3-0.5 \times \Delta^{2} \mathrm{PS}-2
$$

Since for PS-2 and PS-3 the first order difference was the sum of its respective second order difference and the first order difference for PS-1, it follows that the first order difference for PS-4 ( $\triangle \mathrm{PS}-4)$ was the sum of the first order difference for PS- 1 and the second order difference for PS-4. Table 2 shows that $\Delta \mathrm{PS}-4$ is indeed the sum of $\Delta \mathrm{PS}-1$ and $\Delta^{2} \mathrm{PS}-4$. Therefore, PS- 4 could be calculated by subtracting either $\Delta \mathrm{PS}-4$, or the sum of $\Delta \mathrm{PS}-1$ and $\Delta^{2} \mathrm{PS}-4$, from $\mathrm{C}$, as follows:

$$
\text { PS-4 }=\mathrm{C}-\left(\Delta \mathrm{PS}-1+\Delta^{2} \mathrm{PS}-4\right)
$$

\subsection{Projected Crop Areas}

The livestock crop complex (LCC), the area required to support the production of all livestock in Canada [15,30], is an important sustainability issue. The three livestock-specific analyses [12-14] provided LCC areas for each livestock type. The LCC for 2001, the only year common to all three sources [12-14] for which these area inputs were provided, is shown Table 1. For all three sources, only the total area in feed grains, rather than crop-specific areas, was given [12-14]. Hence, the required land used to grow feed grains for the four scenarios assessed in this paper was limited to total Canadian areas of annual crops in each LCC. The areas for P in 2017 were projected from the areas required for $P$ for 2001 (Table 1) and then scaled to areas needed for C in 2017 for beef, pork and broilers, and to the set of PS for these commodities (Table 3). It was assumed that, within each PS, there is no change in how the farmland is managed. Hence, any change in crop areas would be reflected in the GHG emissions from that PS since such a GHG budget change could only result from either increasing or decreasing the quantity of land under that PS. Therefore, the appropriate ratios of GHG emissions from Table 1 could be used as factors to rescale crop areas within each livestock type to estimate the $2017 \mathrm{P}, \mathrm{C}$ and PS-1 to PS-4 areas. To project land use area (A) from 2001 to 2017, the land used in 2001 for P of each livestock type, $i$, was multiplied by the 2017 to 2001 ratio of the respective GHG emissions, as follows:

$$
\mathrm{A}_{i}\{\mathrm{P}, 2017\}=\mathrm{A}_{i}\{\mathrm{P}, 2001\} \times \mathrm{GHG}_{i}\{\mathrm{P}, 2017\} / \mathrm{GHG}_{i}\{\mathrm{P}, 2001\}
$$

To interpolate the land used for $\mathrm{P}$ to the land needed to produce just the quantities of LW consumed in Canada, C, the land area for each livestock type was multiplied by the GHG ratio for each respective livestock type of GHG emissions from the 2017 P to the GHG emissions from 2017 C, as follows:

$$
\mathrm{A}_{i}\{\mathrm{C}, 2017\}=\mathrm{A}_{i}\{\mathrm{P}, 2017\} \times \mathrm{GHG}_{i}\{\mathrm{C}, 2017\} / \mathrm{GHG}_{i}\{\mathrm{P}, 2017\}
$$


Similarly for each PS, the 2017 land use was determined by multiplying the land area used for P in 2017 by the ratio of 2017 GHG emissions from P to the 2017 GHG emissions from each PS. As with C, each PS- $n$ area $(n=1,4)$ was calculated separately for each respective livestock type, as follows:

$$
\mathrm{A}_{i}\{\mathrm{PS}-n, 2017\}=\mathrm{A}_{i}\{\mathrm{P}, 2017\} \times \mathrm{GHG}_{i}\{\mathrm{PS}-n, 2017\} / \mathrm{GHG}_{i}\{\mathrm{P}, 2017\}
$$

For beef production, Vergé et al. [12] also provided the areas in harvestable forages and in pasture. Because most pasture land for beef production is usually not suitable for field crops [31], the highest alternative value and most sustainable use of this land in Canada was as wild habitat and natural biodiversity, and is generally only used for grazing [32,33]. Therefore, pasture land was not considered further and only the possible changes in areas in either annual crops or harvestable forages (Table 3) were used in this analysis. The beef GHG emission ratios that were applied to feed grains for beef were also applied to the land in harvestable forage. Applying Equations (4) and (5) to the 2017 crop areas for C and the four PS required the livestock-specific GHG emissions for 2017 shown in Figure 2 for each livestock type, $i$, along with the livestock-specific 2017 GHG emissions for P from Table 1 . Whereas the livestock-specific GHG emissions for C, PS-1, PS-2 and PS-3 were already available [6], the GHG emissions for PS-4 were calculated in this paper (Equation (2)).

Table 3. Areas in annual crops and harvestable forages required to produce the three livestock commodities consumed in 2017 and in the four production scenarios (PS-1 to PS-4) described in this paper.

\begin{tabular}{cccccc}
\hline & Beef & Pork & Broilers & Total & Beef \\
\hline & grains & grains & grains & grains & roughage \\
\cline { 2 - 6 } & \multicolumn{5}{c}{ Mha } \\
C $^{1}$ & 1.0 & 1.0 & 1.1 & 3.1 & 3.1 \\
PS-1 & 0.8 & 0.7 & 1.5 & 3.0 & 2.3 \\
PS-2 & 0.4 & 0.7 & 1.5 & 2.6 & 4.4 \\
PS-3 & 0.2 & 1.1 & 1.5 & 2.9 & 2.2 \\
PS-4 & 0.4 & 1.1 & 1.5 & 3.0 & 1.2 \\
\hline \multicolumn{7}{c}{ C = Canadian consumption during 2017. }
\end{tabular}

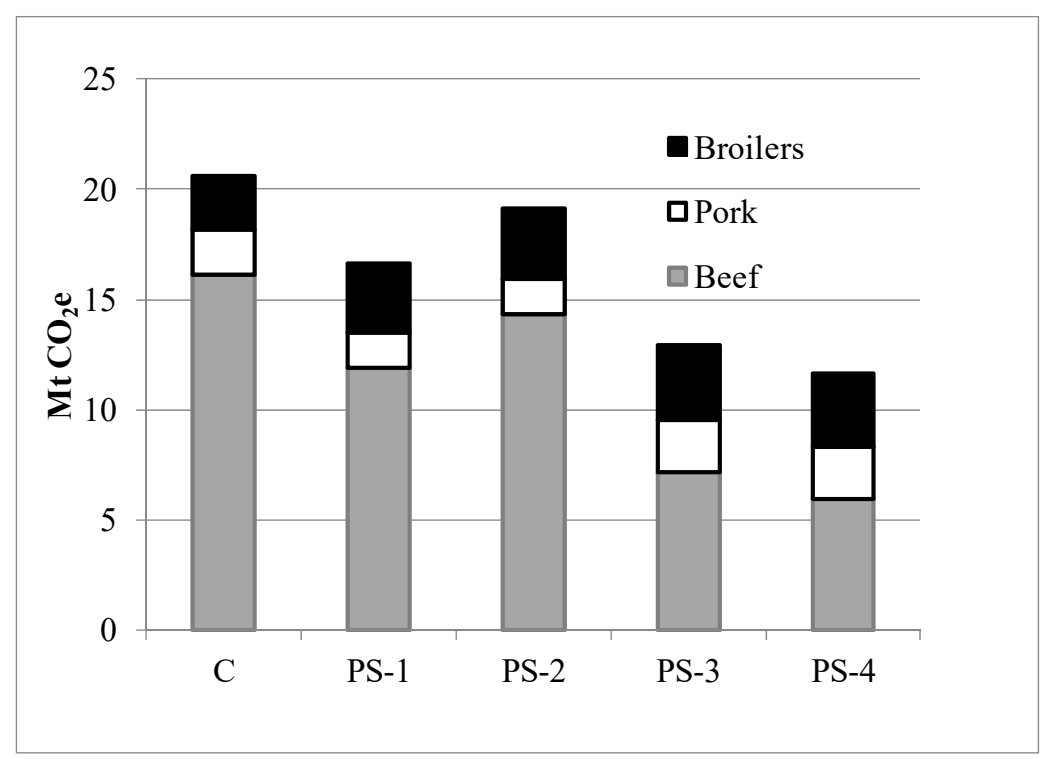

Figure 2. Greenhouse gas (GHG) emissions from the Canadian consumption (C) of beef, pork and broilers, and from four production scenarios (PS-1 to PS-4) for these three commodities in 2017. 
Like the GHG emissions from PS-2, the crop complex areas of PS-2 could not be derived directly from the three livestock-specific GHG emission sources [12-14], due to the GF diet for the slaughter cattle. The diet and lifespan differences between feedlot slaughter cattle and the replacement heifers that were used to determine the GHG emissions from GF beef [6] were applied in this analysis for the forage areas in PS-2. These unpublished data from the unified livestock GHG emissions model [15] allowed the approximation of the difference in crop areas between the GF diet and the BAU diet for slaughter cattle. This area approximation also facilitated the required feed grain and forage areas for PS-3.

\section{Results}

\subsection{Scenario-Based GHG Emissions}

Because the 2017 GHG emissions for each livestock type [6] are direct inputs to area calculations (Equations (3)-(5)), they are shown in Figure 2. GHG emissions for beef (shown in grey) declined from C to PS-1 by $25 \%$, then increased by $20 \%$ from PS-1 to PS-2. Whereas GHG emissions for beef are appreciably higher than for pork and broilers in all four PS, the beef GHG emissions in PS-3 and PS-4 reflect the halving of the weight of beef consumption to allow more pork consumption. The PS-3 GHG emissions for beef were half of the PS-2 GHG emissions, and PS-4 GHG emissions for beef were half of the PS-1 GHG emissions. For pork (shown in white), the GHG emissions were below the GHG emissions estimate for $\mathrm{C}$ by the same amount for both PS- 1 and PS-2. But the $50 \%$ increase in pork consumption [6] made the pork GHG emissions for PS-3 and PS-4 slightly greater than the pork GHG emissions for C. These RM redistribution assumptions made the 2017 GHG emissions for broilers (shown in black) greater than the 2017 GHG emissions for C by roughly the same amounts in all four PS.

The three-commodity total GHG emissions for 2017 consumption and the four scenarios in this paper are shown in line 1 of Table 2 and the differences between the 2017 GHG emissions for $\mathrm{C}$ and each PS ( $\triangle \mathrm{PS}-n)$ are shown in line 2 of Table 2. For PS-1, the GHG reductions from C were $3.9 \mathrm{Mt}^{\mathrm{CO}} \mathrm{O}_{2} \mathrm{e}$, while the GHG reductions for PS-2 were only $1.5 \mathrm{Mt} \mathrm{CO}_{2}$ e. For PS-3, the GHG reductions were $7.7 \mathrm{Mt}$ $\mathrm{CO}_{2} \mathrm{e}$, while for PS-4, the GHG reductions increased to $8.9 \mathrm{Mt} \mathrm{CO}_{2} \mathrm{e}$. Except for PS-2, three of the PS showed a steady decline from $\mathrm{C}$. Whereas the GHG emissions from C were $61 \%$ of GHG emissions from P (Table 1, line 4), the GHG emissions from PS- 1 to PS4 were $50 \%, 57 \%, 38 \%$ and $35 \%$ of the GHG emissions from $\mathrm{P}$, respectively. Expressing the first order differences ( $\Delta$ PS- $n$ ) from Table 2 (line 2 ) as percentages of $C$ show their relative magnitudes. PS- 1 decreased the GHG emissions from $C$ by $19 \%$, whereas PS-2 only decreased the consumption-related GHG emissions from C by 7\%. For PS-3 and PS-4, where the allowed beef consumption was cut in half, the GHG emission reductions were $37 \%$ and $43 \%$ of $C$, respectively.

The second order differences ( $\Delta^{2} \mathrm{PS}-n$ ) between $\Delta \mathrm{PS}-1$ and each of $\Delta \mathrm{PS}-2, \Delta \mathrm{PS}-3$ and $\Delta \mathrm{PS}-4$ are shown in lines 3 and 4 of Table 2. For PS-3, the GHG reductions from $\Delta$ PS-1 ( $\Delta^{2}$ PS-3) were only $3.8 \mathrm{Mt}$ $\mathrm{CO}_{2} \mathrm{e}$. For PS-4, the GHG reductions from $\Delta$ PS-1 ( $\left.\Delta^{2} \mathrm{PS}-4\right)$ were $5.0 \mathrm{Mt} \mathrm{CO}_{2} \mathrm{e}$. At $-2.5 \mathrm{Mt} \mathrm{CO}_{2} \mathrm{e}, \Delta^{2} \mathrm{PS}-2$ demonstrates that shifting from the BAU to GF diet for beef would increase GHG emissions. $\Delta^{2} \mathrm{PS}-3$ and $\Delta^{2}$ PS- 4 were $18 \%$ and $24 \%$ of the GHG emissions related to C, respectively. The difference between $\Delta^{2}$ PS-3 and $\Delta^{2}$ PS- 4 was half of the absolute value of $\Delta^{2}$ PS-2, which was $12 \%$ of the GHG emissions related to $C$.

\subsection{Projected Scenario Land Use}

Table 3 shows that the farm areas required to grow the feed grains needed to produce the quantities of $\mathrm{LW}$ for $\mathrm{C}$ (Line 1) were about equal across the three livestock types. For beef, the feed grain area needed for $\mathrm{P}$ (Table 1, Line 6) was $63 \%$ higher than the area needed by C (Table 3). For pork, the area needed for $\mathrm{P}$ (Table 1 ) was almost three times as large as for $\mathrm{C}$ (Table 3 ). The feed grain area needed to produce the broilers consumed by Canadians (Table 3), however, exceeded the area of feed grains used 
for actual domestic broiler production (Table 1) by 32\%, reflecting the failure of the 2017 Canadian broiler production to meet Canadian consumer demand. The LW ratio for $\mathrm{C}$ to $\mathrm{P}$ for broilers confirms that broiler consumption exceeded Canadian production by 32\% in 2017 [6]. Across all three commodities, the feed grain area for $P$ exceeded the feed grain area for $C$ by $71 \%$.

The PS-1 (Table 3, line 2) feed grain areas for beef and pork were both approximately three quarters of the feed grain areas needed for C (Table 3, line 1), whereas the feed grain area needed to produce the broilers for Canadian consumption was $34 \%$ above the area needed to produce the broilers for C during 2017. For PS-2 (Table 3, line 3), the feed grain area for beef decreased by 50\%. For PS-3, Table 3 (line 4) shows a further decrease in feed grain area for beef, with an increase in areas for pork, while the feed grain area for broilers remained the same as it was for PS-1 and PS-2. For PS-4 (line 5), the beef feed grain area returned to almost the same feed grain area as was required for beef in PS-2, but twice the feed grain area for PS-3. The feed grain areas for pork and broilers were the same as for PS-3

None of the four PS used more land for feed grains for the three commodities combined (Table 3 , column 4) than was used for the total feed grains for C. The scenario that used the lowest share of land for feed grains for all three livestock types was PS-2, at $84 \%$ of the feed grain area accounted for by C, and $49 \%$ of the feed grain area used for P (Table 1). The scenario that used the most feed grain area was PS- 4 , at $98 \%$ of the area for C and $59 \%$ of the feed grain area for total P. PS- 1 and PS-3 used $96 \%$ and $92 \%$, respectively, of the feed grain area accounted for by Canadian consumption of these three commodities in 2017. The reason for the PS-1, PS-3 and PS-4 grain areas being so close to the grain area used for $\mathrm{C}$ was due to the increased broiler production to satisfy NPI. All four scenarios called for a $40 \%$ increase in feed grain area for broilers to meet the expanded broiler consumption, which was double the feed grain area for the 2017 broiler production.

For the harvestable forage area (Table 3, column 5), which only affects beef, PS-1 required $74 \%$ of the forage area for C, while the forage area required for PS-3 decreased to just below those for PS-1, at $69 \%$. Only PS-2, at $139 \%$ of the forage area for C, used more land for forage production than the forage-producing land accounted for by Canadian consumption, which was nearly double the forage area used in PS-1. The land for forage required by PS- 2 was 2.5 times as high as the land that this scenario saved from growing annual crops (compared to C). PS-4 was the least dependent on forage, at $37 \%$ of the forage-producing area accounted for by Canadian consumption. None of the scenarios required more land than $\mathrm{P}$ to grow forage.

For this analysis, the crop areas for $\mathrm{C}$ and $\mathrm{P}$ (Tables 1 and 3 ) were related to the sector-wide farmland in Canada. The total cropland required for P in this analysis was 10.3 Mha for 2017 and 11.6 Mha for 2001 (Table 1). In 2001 the farmland, not including land in seeded pasture, was 31.2 Mha [34]. For 2016 the land in crops, with seeded pasture excluded, was 32.7 Mha [35]. Dyer et al. [30] reported 33.5 Mha of total farmland in Canada for 2001, of which 14.0 Mha were included in the total LCC for 2001, including dairy, along with beef, pork and poultry. Vergé et al. [36], using methodology similar to that used for beef, pork and broilers [12-14], estimated the crop complex for the Canadian dairy industry to be 2.9 Mha. This dairy area estimate, combined with the area estimate of 11.6 Mha for 2001 from this analysis, gave 14.5 Mha for the four livestock commodities, only $4 \%$ higher than the 2001 LCC estimate from Dyer et al. [30]. The 2001 LCC area usage (feed grain plus harvestable forage) for beef, pork and broilers of 11.6 Mha accounted for approximately $35 \%$ to $37 \%$ of the farmland in Canada. Because the 2001 total farmland estimate used in this comparison excluded permanent pasture and rangeland, the share of total arable land in Canada would have been lower. The land required for $P$ in 2017 (10.3 Mha) would have used 32\% of the 32.7 Mha of available farmland, and the 6.3 Mha required to satisfy C in 2017 (Table 3) would have used 19\% of the total farmland in 2017. The four PS would have used $16 \%, 21 \%, 15 \%$ and $13 \%$, respectively, of total farmland.

\subsection{Scenario Impacts on Sector-Wide GHG}

Figure 3 shows the Canadian production and consumption of beef, pork and broilers, and the four scenarios as percentages of the sector-wide GHG emissions of Canadian agriculture. The GHG 
emissions for $\mathrm{P}$ (white and grey segments of just the bar for C) accounted for $47 \%$ of the $72 \mathrm{Mt}^{\mathrm{CO}_{2} \mathrm{e}}$ GHG emissions 2017 total from the Canadian agriculture sector [11]. The consumption of these commodities by Canadians (white segment of just the bar for C) accounted for $29 \%$ of the sector-wide GHG emissions. The shares of the total GHG emissions that PS-1 to PS-4 (the black segments of the four bars for PS) account for are 23\%, 27\%, 18\% and 16\%, respectively, of sector-wide GHG emissions.

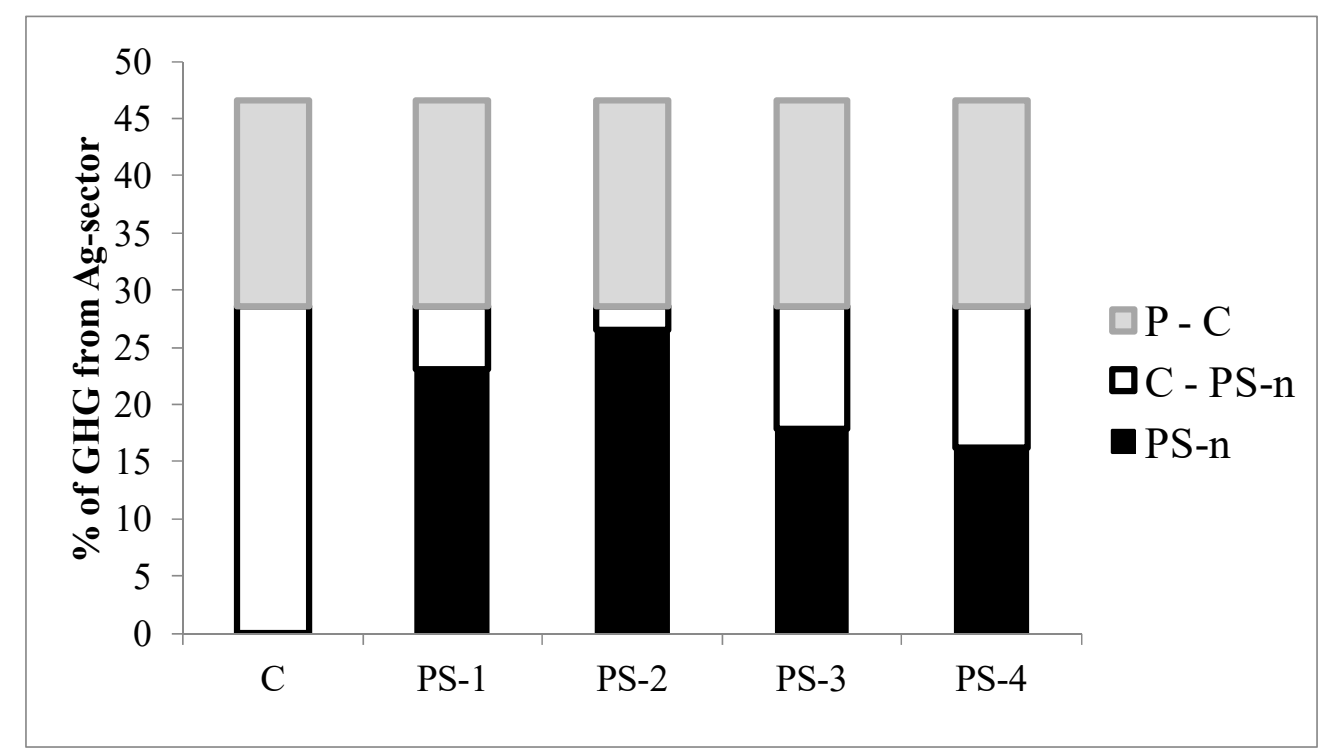

Figure 3. GHG emissions from P, C and PS- $n$ from beef, pork and broilers, and GHG emission differences between P and C $(\mathrm{P}-\mathrm{C})$, and between C and PS- $n(\mathrm{C}-\mathrm{PS}-n)$ expressed as percentages of the total GHG emissions from the Canadian agriculture sector in 2017, where $n=1$ to 4 .

The PS-related GHG emission reductions from C are shown in Figure 3 by the white segments of the four bars for PS. PS-4, the most effective of the four scenarios, would reduce the sector-wide GHG emissions by $12.4 \%$, with PS-3 reducing the sector-wide GHG emissions by $10.7 \%$. PS-2, the least effective of the four scenarios, would only reduce the sector-wide GHG emissions by $2.0 \%$, while PS- 1 would reduce the sector-wide GHG emissions by $5.4 \%$. The white segments of the four PS bars in Figure 3 illustrate graphically the $\Delta$ PS- $n$ calculations in Table 2.

Subtracting the GHG emissions due to the medical recommendation (white segment of the PS-1 bar) from the emissions by PS-3 and PS-4 (white segments of the 4th and 5th bars), demonstrates that apportioning more RM to pork and cutting beef consumption from PS-1 and PS-2 in half accounted for $5.2 \%$ of the sector's GHG emissions in PS-3 and 6.9\% in PS-4. However, subtracting the white segment of the PS-1 bar from the white segments of the GF the PS-2 bar resulted in an increase in the sector's GHG emissions by $3.4 \%$. The differences among the white segments of the four PS bars in Figure 3 illustrate graphically the $\Delta^{2}$ PS- $n$ calculations in Table 2.

\section{Discussion}

This scenario analysis is underpinned by the GHG-protein indicator $[6,10,15,17]$. The starting point for this paper was the premise that both medical and producer considerations had a potential role to play in reducing livestock GHG emissions [6]. Projections to 2026 by OECD [29] indicate that Canadian RM consumption would change little from 2017 just due to market forces. Therefore, realizing PS-1 would depend on proactively promoting the medical incentive. Whatever motivation can be employed to promote reduced RM consumption in Canada, both health and environmental benefits can be expected $[1,8,9]$. Therefore, coupled with such proactive promotion, PS-1 is not an unreasonable expectation. 


\subsection{Livestock Management and Consumer Choices}

The previous beef-pork-broiler analysis [6] was limited to a select set of integrated scenarios, which identified the impacts of increasing the share of RM to pork, changes in the beef diet and the medical recommendations. But it did not differentiate the production scenarios from the impact of the medical RM recommendations. The main departure from the original scenario analysis [6] was that this analysis separated the consumer and producer responses by disaggregating the scenario-related GHG emissions. The result was the first order differences for PS- 1 to PS-4 from C, and the second order differences for PS-2 to PS-4 from the first order difference for PS-1 (Table 2). To understand the role of producer responses, three of the first order differences ( $\triangle \mathrm{PS}-2$ to $\triangle \mathrm{PS}-4)$ had to be further disaggregated from the medical impact ( $\Delta$ PS-1). The second order differences ( $\Delta^{2}$ PS-2 to $\left.\Delta^{2} P S-4\right)$, as shown in Table 2, isolated and defined the two producer responses considered here-beef diet and commodity shifts. Environmentally minded consumers can take guidance from the second order differences, at least from the perspective of the sector's carbon footprint. This guidance provides an understanding that GF beef has an added GHG emission cost, whereas the shift from beef to pork would reduce GHG emissions.

With broilers having a lower GHG emission intensity than pork [10], raising the share of broilers in the NPI at the expense of RM (either pork or beef) could reduce GHG emissions more than the boundary conditions that this analysis allowed. Because the 2017 broiler consumption exceeded Canadian broiler production, it was assumed that any broiler consumption increase would be met by an increase in Canadian production, rather than by imported broilers. Therefore, this scenario analysis had to maintain Canadian broiler consumption and production within the maximum RM and minimum NPI boundary conditions in order to fully capture and quantify the impact of the medically based RM reductions on the carbon footprint of Canadian livestock.

The addition of PS-4 to this scenario analysis was clearly helpful in segregating feedlot finished (BAU) beef from GF beef. Whereas $\Delta^{2}$ PS-4 required a special calculation (Equation (1)), it represents the impact of the increased apportionment of pork to RM. $\Delta^{2}$ PS-3 was unable to show this because it included the impact of GF beef, which was isolated and defined by $\Delta^{2} \mathrm{PS}-2$. The comparison of the magnitudes (sign ignored) of $\Delta^{2}$ PS-2 and $\Delta^{2}$ PS-4 (Table 2), demonstrates that, in the context of this scenario analysis, shifting RM consumption from beef to pork (50:50 to 25:75) beef-pork split) had twice the effect on the agriculture GHG emissions in Canada as changing the beef diet BAU to/from GF.

\subsection{Scenario Analysis Implications}

Expanding the scenario analysis to include the required crop areas introduced an additional sustainability condition. Hence, maintaining the same 2017 export rates for beef and pork products for each PS emerged as a third boundary condition whereby the area difference between $\mathrm{P}$ and $\mathrm{C}$ had to be maintained. This required that the cropland used by a PS must not exceed the land area required for domestic consumption. All four scenarios indicate that the cropland required to grow feed grains for the three selected livestock types is clearly not going to exceed this land use threshold, so no grain-growing land would need to be taken from the livestock products destined for export. Similarly, it follows that none of the PS land use would need to take cropland from the grains and oilseeds grown for either human consumption or industrial use. For forage, however, PS-2 exceeded the area based boundary condition.

If the GF diet for beef (PS-2) was either avoided or only allowed when the beef population was reduced (as in PS-3), then forage growing land can be freed from the production of animal protein. Because the forage requirement for PS- 2 was $35 \%$ higher than the forage area required for C, an increase in GF beef may not be feasible. The lower GHG emissions shown in Table 2 for PS-1, PS-3 and PS-4 support the avoidance of PS-2. The freed farmland from PS-2 could be returned to natural habitat, which would have either the same or better carbon sequestration benefit as perennial forage and would also enhance natural biodiversity [31], thus broadening sustainability. Because PS-1, PS-3 and PS- 4 can maintain the same NPI as PS- 2 without using the $35 \%$ surplus forage land from PS-2, any sequestered $\mathrm{CO}_{2}$ related to this forage area could not be credited to PS-2 in this analysis. Furthermore, 
if the freed land from PS-2 was needed for either human food or industrial use, its potential role in carbon sequestration could be forfeited [26] without any impact on the other three PS.

This analysis suggests that diverting feed grains from beef cattle to nonruminants (pork and broilers) is a more effective strategy than changing the beef diet to include feed grains, even though the BAU beef diet generated less GHG emissions than GF beef. Aside from the ruminant methane emitted by cattle, both pigs and chickens have a much higher fecundity (effective reproduction and growth rates) than beef cattle. Consequently, the breeding populations that must be maintained to produce the market animals are much smaller for both pork and broilers than for beef [15]. Although this conclusion is not unique to this livestock-type GHG emissions comparison [10,16], this scenario analysis highlights this difference as a basis for consumer food choices. Commodity diversification, driven by consumer choices, particularly for either pork or broilers over beef to satisfy their dietary protein, can help reduce GHG emissions from Canadian agriculture. The effectiveness of the shift from beef to pork in reducing GHG emissions is demonstrated in Table 2 by the magnitude of $\Delta^{2}$ PS- 4 being twice the magnitude of $\Delta^{2}$ PS-2. Although broilers are the most popular non-RM protein source [23], this commodity is only one example for how consumers can diversify their protein sources beyond RM [5], many of which have lower GHG-protein emission intensities than broilers $[17,20]$. The difference in GHG emission intensity between pork and broiler production was less than the difference between either of these two commodities and beef. These intensity differences suggest that NPI could be maintained while GHG emissions would still be reduced by consuming less beef (either BAU or GF) and more nonruminants.

The previous beef-pork-broiler scenario analysis [6] cautioned that its results were based on simulation and should only be used in relative comparisons. A further caution from this analysis concerns the projection forward of the 2001 GHG emission simulations [12-14] to 2017 because of changes in production technology, whereas livestock populations were the only variable with sufficient historical data to be used for projecting the 2001 GHG emissions to 2017. Tracking the changes over time that can be expected for feed grain supply was beyond the scope of this analysis. However, since all three livestock types rely on the same feed grain, the impact of such changes should be muted. Ultimately, these precision shortcomings do not limit the main value of this analysis, which is the disaggregation of the production scenarios to compare their relative individual impacts on the sustainability of the Canadian livestock industry.

\section{Conclusions}

Although the three commodities contribute almost half of the sector-wide GHG emissions, the impact of the scenarios on land use was minimal. This was because RM reductions were replaced in all the scenarios by one of the other carcass commodities in order to maintain NPI. For example, increasing broiler consumption did not nullify the potential of the scenarios in reducing the GHG emissions. Nor did it increase the need for feed grain areas beyond what domestic consumption of these three livestock types already required in 2017. This result was achieved in spite of the fact that the crop area to support broilers in $\mathrm{C}$ and all four scenarios were higher than for $\mathrm{P}$ for broilers, due to broilers being a net imported commodity.

Acceptance of the average medical recommendation to reduce RM consumption used in this analysis, without any other consumer responses, could reduce the GHG emissions from Canadian agriculture by approximately $4 \mathrm{Mt} \mathrm{CO}_{2} \mathrm{e}$. This gives Canadian consumers an indirect role to play in reducing Canadian agricultural GHG emissions, even though that was not the aim of the food guide. This unintended (or at least unstated) pathway towards reduced GHG emissions captured by the food guide was facilitated by the large differences between the GHG emission intensities of beef and both pork and broiler production [6]. This analysis suggests that consumers can also significantly reduce GHG emissions from Canadian agriculture by either choosing pork over beef, or even more by choosing domestically produced broilers over RM. Although beyond the scope of this scenario 
analysis, it is implicit that broilers are a proxy for any other non-RM, low carbon footprint, complete protein source that is otherwise environmentally sustainable.

At least within the context of this scenario analysis, there appears to be little advantage in using the GF beef diet to convert annual cropland into permanent forage from a protein supply perspective. The soil carbon sequestration potential associated with PS-2 is not lost in PS-1, PS-3 or PS-4 simply because that potential was not required in those three scenarios. It does not appear to make sense to either maintain or expand beef production while also converting BAU beef to GF beef, even when soil carbon is considered. However, if more feed grain is apportioned to either pork or poultry and away from beef, then some GF beef may be accommodated without either raising GHG emissions or increasing land use compared to $\mathrm{C}$.

Finally, because the scenarios all maintained the NPI, the commodity shifts suggested in this analysis should not lead to a major loss in farm livelihoods, another component of sustainability. These shifts simply mean that more feed grains would be fed to nonruminants, rather than ruminants. Invoking the NPI as a lower boundary condition suggests that there is an opportunity to expand the broiler industry, an equal but different livestock market into which feed grains can be sold. For the most part, maintaining NPI from domestic products should maintain Canadian farm incomes (carcass commodity price differences notwithstanding) without compromising livestock product exports. The cropland assessment (Table 3) suggests that this is feasible. Given the very high GHG emission intensity of beef, it should not be surprising that this analysis found that diversifying Canadian protein intake away from beef to be such an attractive option for lowering the GHG emission budget of the Canadian agriculture sector.

Author Contributions: Conceptualization, J.A.D. and R.L.D.; Methodology, J.A.D.; Resources, X.P.V.; D.E.W.; Writing-Original Draft Preparation, J.A.D.; Writing-Review \& Editing, R.L.D. and X.P.V.; D.E.W.; Funding Acquisition, R.L.D. All authors have read and agreed to the published version of the manuscript.

Funding: This research was funded by: the Sustainability Metrics Project, Contract No. 01E86 2018-2019, Agriculture and Agri-food Canada, Government of Canada.

Conflicts of Interest: The authors declare no conflict of interest.

$\begin{array}{ll}\text { Abbreviations } & \\ \text { GHG } & \text { Greenhouse Gas } \\ \text { LW } & \text { Live Weights } \\ \text { CW } & \text { Carcass Weights } \\ \text { RM } & \text { Red Meat } \\ \text { P } & \text { Production } \\ \text { C } & \text { Consumption } \\ \text { NPI } & \text { National Protein Intake } \\ \text { PS } & \text { Production Scenario } \\ \text { OECD } & \text { Organization for Economic Co-operation and Development } \\ \text { FAO } & \text { Food and Agriculture Organization of the United Nations } \\ \mathrm{n} & \text { PS number } \\ \Delta & \text { Difference } \\ \Delta \text { PS- } n & \text { First order difference } \\ \Delta^{2} \text { PS- } n & \text { Second order difference } \\ \text { A } & \text { Land use Area } \\ \text { LCC } & \text { Livestock Crop Complex } \\ \text { BAU } & \text { Business As Usual } \\ \text { GF } & \text { Grass Fed }\end{array}$

\section{References}

1. Hedenus, F.; Wirsenius, S.; Johansson, D.J.A. The importance of reduced meat and dairy consumption for meeting stringent climate change targets. Clim. Chang. 2014, 124, 79-91. [CrossRef] 
2. Gerber, P.J.; Steinfeld, H.; Henderson, B.; Mottet, A.; Opio, C.; Dijkman, J.; Falcucci, A.; Tempio, G. Tackling Climate Change through Livestock-A Global Assessment of Emissions and Mitigation Opportunities; Food and Agriculture Organization of the United Nations (FAO): Rome, Italy, 2013; Available online: http://www.fao.org/3/a-i3437e.pdf (accessed on 8 May 2020).

3. Government of Canada. Canada's Food Guide-Healthy Eating and the Environment. Date Modified: 2019-01-14. Available online: https://food-guide.canada.ca/en/tips-for-healthy-eating/healthy-eating-andthe-environment/ (accessed on 2 May 2020).

4. Flanagan, R. What's on Your Plate? Inside the Changes to Canada's Food Guide. CTVNews. 23 January 2019. Available online: https://www.ctvnews.ca/health/what-s-on-your-plate-inside-the-changes-to-canadas-food-guide-1.4265399 (accessed on 15 May 2020).

5. Kramer, L. The Future of Meat is Shifting to Plant-Based Products. Department of Management, University of Toronto. Available online: https://www.utoronto.ca/news/future-meat-shifting-plant-based-products-u-texpert (accessed on 15 May 2020).

6. Dyer, J.A.; Worth, D.E.; Vergé, X.P.C.; Desjardins, R.L. Impact of recommended red meat consumption in Canada on the carbon footprint of Canadian livestock production. J. Clean. Prod. 2020, 266, 121785. [CrossRef]

7. Shakeri, S. Dietitian Breaks Down Andrew Scheer's Food Guide Comments. HuffPost Canada. Available online: https:/www.huffingtonpost.ca/entry/andrew-scheer-food-guide-fact-check_ca_ 5d3268c1e4b0419fd32d31de? (accessed on 15 May 2020).

8. Veeramani, A. Carbon Footprinting Dietary Choices in Ontario: A life cycle approach to assessing sustainable, healthy \& socially acceptable diets. In A Thesis Presented to the University of Waterloo in Fulfillment of the Thesis Requirement for the Degree of Master of Environmental Studies in Sustainability Management; Waterloo University: Waterloo, ON, Canada, 2015; p. 173.

9. Heller, M.C.; Keoleian, G.A. Greenhouse gas emission estimates of US dietary choices and food loss. J. Ind. Ecol. 2015, 19, 391-401. [CrossRef]

10. Dyer, J.A.; Vergé, X.P.C.; Desjardins, R.L.; Worth, D.E. The protein-based GHG emission intensity for livestock products in Canada. J. Sustain. Agric. 2010, 34, 618-629. [CrossRef]

11. ECCC. National Inventory Report 1990-2017: Greenhouse Gas Sources and Sinks in Canada. Table A10-2 Canada's GHG Emissions by Canadian Economic Sector, 1990-2017. Environment and Climate Change Canada (ECCC). Cat. No.: En81-4/1E-PDF, ISSN: 2371-1329. Available online: http://publications.gc.ca/ collections/collection_2019/eccc/En81-4-2017-3-eng.pdf (accessed on 3 June 2020).

12. Vergé, X.P.C.; Dyer, J.A.; Desjardins, R.L.; Worth, D. Greenhouse gas emissions from the Canadian beef industry. Agric. Syst. 2008, 98, 126-134. [CrossRef]

13. Vergé, X.P.C.; Dyer, J.A.; Desjardins, R.L.; Worth, D. Long Term trends in greenhouse gas emissions from the Canadian poultry industry. J. Appl. Poult. Res. 2009, 18, 210-222. [CrossRef]

14. Vergé, X.P.C.; Dyer, J.A.; Desjardins, R.L.; Worth, D. Greenhouse gas emissions from the Canadian pork industry. Livest. Sci. 2009, 121, 92-101. [CrossRef]

15. Vergé, X.P.C.; Dyer, J.A.; Worth, D.E.; Smith, W.N.; Desjardins, R.L.; McConkey, B.G. A greenhouse gas and soil carbon model for estimating the carbon footprint of livestock production in Canada. Animals 2012, 2, 437-454. [CrossRef] [PubMed]

16. Poore, J.; Nemecek, T. Reducing food's environmental impacts through producers and consumer. Science 2018, 360, 987-992. [CrossRef] [PubMed]

17. Dyer, J.A.; Vergé, X.P.C.; Desjardins, R.L.; Worth, D.E. District Scale GHG Emission Indicators for Canadian Field Crop and Livestock Production. Agronomy 2018, 8, 190. [CrossRef]

18. Desjardins, R.L.; Worth, D.E.; Vergé, X.P.C.; Maxime, D.; Dyer, J.; Cerkowniak, D. Carbon Footprint of Beef Cattle. Sustainability 2012, 4, 3279-3301. [CrossRef]

19. Sabia, E.; Kühl, S.; Flach, L.; Lambertz, C.; Gauly, M. Effect of Feed Concentrate Intake on the Environmental Impact of Dairy Cows in an Alpine Mountain Region Including Soil Carbon Sequestration and Effect on Biodiversity. Sustainability 2020, 12, 2128. [CrossRef]

20. Dyer, J.A.; Vergé, X. The Role of Canadian Agriculture in Meeting Increased Global Protein Demand with Low Carbon Emitting Production. Agronomy 2015, 5, 569-586. [CrossRef] 
21. Statistics Canada Table 32-10-0130-01 Number of cattle, by class and farm type $(\times 1,000)$. Date modified: 2019-03-05. Available online: https://www150.statcan.gc.ca/t1/tbl1/en/tv.action?pid=3210013001 (accessed on 15 May 2020).

22. Janzen, H.H.; Desjardins, R.L.; Asselin, J.M.R.; Grace, B. (Eds.) The Health of Our Air-Toward Sustainable Agriculture in Canada. Available online: https://atrium.lib.uoguelph.ca/xmlui/bitstream/handle/10214/15124/ FDMR_healthy_air.pdf?sequence=1\&isAllowed=y (accessed on 2 July 2020).

23. AAFC. Protein Disappearance of Animal Protein Sources in Canada-Per Capita Disappearance. Agriculture and Agri-food Canada (AAFC). Available online: http://www.agr.gc.ca/eng/animal-industry/ poultry-and-eggs/poultry-and-egg-market-information/industry-indicators/per-capita-disappearance/ ?id=1384971854413 (accessed on 27 April 2020).

24. Beauchemin, K.A.; McGinn, S.M. Methane emissions from feedlot cattle fed barley or corn diets. J. Anim. Sci. 2005, 83, 653-661. [CrossRef] [PubMed]

25. Van Haarlem, R.P.; Gao, A.Z.; Desjardins, R.L.; Flesch, T.K. Methane and ammonia emissions from a commercial beef feedlot. Can. J. Anim. Sci. 2008, 88, 641-649. [CrossRef]

26. Liang, C.; MacDonald, J.D.; Desjardins, R.L.; McConkey, B.G.; Beauchemin, K.A.; Flemming, C.; Cerkowniak, D.; Blondel, A. Beef cattle production impacts soil carbon storage. Sci. Total Environ. 2020, 718, 137273. [CrossRef] [PubMed]

27. Dyer, J.A.; Vergé, X.P.C.; Desjardins, R.L.; McConkey, B.G. Implications of biofuel feedstock crops for the livestock feed industry in Canada. In Environmental Impact of Biofuels; InTech Open Access Publisher: Rijeka, Croatia, 2011; p. 270. Available online: https://www.intechopen.com/books/environmental-impact-ofbiofuels/implications-of-biofuel-feedstock-crops-for-the-livestock-feed-industry-in-canada (accessed on 26 May 2020).

28. Elward, M.; McLaughlin, B.; Alain, B. Livestock Feed Requirements Study 1999-2001. Catalogue No. 23-501-XIE, Statistics Canada. Available online: https://www150.statcan.gc.ca/n1/en/pub/23-501-x/23-501x2003001-eng.pdf?st=AEOSZEeY (accessed on 21 April 2020).

29. OECD. Meats-OECD-FAO Agricultural Outlook 2017-2026. Organization for Economic Co-operation and Development (OECD). Available online: https://stats.oecd.org/index.aspx?queryid=76854\# (accessed on 27 April 2020).

30. Dyer, J.A.; Vergé, X.P.C.; Kulshreshtha, S.N.; Desjardins, R.L.; McConkey, B.G. Areas and greenhouse gas emissions from feed crops not used in Canadian livestock production in 2001. J. Sustain. Agric. 2011, 35, 780-803. [CrossRef]

31. Dyer, J.A.; Hendrickson, O.Q.; Desjardins, R.L.; Andrachuk, H.L. An Environmental Impact Assessment of Biofuel Feedstock Production on Agro-Ecosystem Biodiversity in Canada. In Agricultural Policies: New Developments; Laura, M., Ed.; Nova Science Publishers Inc.: Hauppauge, NY, USA, 2011; p. 281. ISBN 978-1-61209-630-8.

32. Howarth, R.W.; Bringezu, S.; Bekunda, M.; de Fraiture, C.; Maene, L.; Martinelli, L.; Sala, O. Rapid assessment on biofuels and environment: Overview and key findings. In Biofuels: Environmental Consequences and Interactions with Changing Land Use; Cornell University: Ithaca, NY, USA, 2009; Available online: https://ecommons.cornell.edu/handle/1813/46196 (accessed on 23 April 2020).

33. UNEP. Towards Sustainable Production and Use of Resources: Assessing Biofuels; United Nations Environmental Program (UNEP): Paris, France, 2009; ISBN1 978-92-807-3052-4. Available online: http://www.unep.fr/shared/ publications/pdf/WEBx0149xPA-AssessingBiofuelsSummary.pdf (accessed on 21 December 2019)ISBN2 978-92-807-3052-4.

34. Statistics Canada. Snapshot of Canadian Agriculture. 2006. Available online: https://www150.statcan.gc.ca/ n1/ca-ra2006/articles/snapshot-portrait-eng.htm (accessed on 15 May 2020.).

35. Statistics Canada. Table 32-10-0406-01: Land Use 2020; Government Canada: Ottawa, ON, Canada, 2020. [CrossRef]

36. Vergé, X.P.C.; Dyer, J.A.; Desjardins, R.L.; Worth, D. Greenhouse gas emissions from the Canadian dairy industry during 2001. Agric. Syst. 2007, 94, 683-693. [CrossRef]

(C) 2020 by the authors. Licensee MDPI, Basel, Switzerland. This article is an open access article distributed under the terms and conditions of the Creative Commons Attribution (CC BY) license (http://creativecommons.org/licenses/by/4.0/). 